\title{
Induction and blockage of oligodendrogenesis by differently activated microglia in an animal model of multiple sclerosis
}

\author{
Oleg Butovsky, ${ }^{1}$ Gennady Landa, ${ }^{1,2}$ Gilad Kunis, ${ }^{1}$ Yaniv Ziv, ${ }^{1}$ Hila Avidan, ${ }^{1}$ Nadav Greenberg, ${ }^{1}$ \\ Adi Schwartz, ${ }^{1}$ Igor Smirnov, ${ }^{3}$ Ayala Pollack, ${ }^{2}$ Steffen Jung, ${ }^{4}$ and Michal Schwartz ${ }^{1}$ \\ ${ }^{1}$ Department of Neurobiology, Weizmann Institute of Science, Rehovot, Israel. ${ }^{2}$ Kaplan Medical Center, Rehovot, Israel. \\ ${ }^{3}$ Proneuron Biotechnologies, Ness Ziona, Israel. ${ }^{4}$ Department of Immunology, Weizmann Institute of Science, Rehovot, Israel.
}

\begin{abstract}
The role of activated microglia (MG) in demyelinating neurodegenerative diseases such as multiple sclerosis is controversial. Here we show that high, but not low, levels of IFN- $\gamma$ (a cytokine associated with inflammatory autoimmune diseases) conferred on rodent MG a phenotype that impeded oligodendrogenesis from adult neural stem/progenitor cells. IL-4 reversed the impediment, attenuated TNF- $\alpha$ production, and overcame blockage of IGF-I production caused by IFN- $\gamma$. In rodents with acute or chronic EAE, injection of IL-4-activated MG into the cerebrospinal fluid resulted in increased oligodendrogenesis in the spinal cord and improved clinical symptoms. The newly formed oligodendrocytes were spatially associated with MG expressing MHC class II proteins and IGF-I. These results point to what we believe to be a novel role for MG in oligodendrogenesis from the endogenous stem cell pool.
\end{abstract}

\section{Introduction}

Recovery from acute insults or chronic inflammatory and noninflammatory degenerative disorders in the CNS has been attributed to a limited capacity for neurogenesis and oligodendrogenesis, poor regeneration of injured nerves, and extreme vulnerability to degenerative conditions. Studies have demonstrated that the adult CNS contains stem cells that can give rise, albeit to a limited extent, both to neurons (1) and to oligodendrocytes (2) throughout life. Knowledge of the factors allowing such stem cells to exist, proliferate, and differentiate in the adult individual is a prerequisite for understanding and promoting the conditions conducive to CNS repair. This in turn can be expected to lead to the development of interventions aimed at boosting neural cell renewal from the endogenous stem cell pool or from exogenously applied stem cells.

Studies have shown that inflammation within the CNS blocks neurogenesis $(3,4)$ and causes structural damage to myelin $(5,6)$. Moreover, "paralysis" of microglia (MG) and/or macrophages arrests progression of the transient monophasic disease $\operatorname{EAE}(7,8)$. All of those findings were interpreted as evidence in support of the traditional view that the effect of local immune cells in the CNS is detrimental, and hence that recovery would require blockage, arrest, or elimination of local immune responses. Likewise, the limited regeneration and excessive vulnerability of CNS neurons under inflammatory conditions or after an acute insult were put down to the poor ability of the CNS to tolerate the immune-derived defensive activity that is often associated with local inflammation and cytotoxicity mediated, for example, by TNF- $\alpha$ (reviewed in refs. 5, 9) or nitric oxide (10). More recent studies have shown, however, that although an uncontrolled local immune response indeed impairs

Nonstandard abbreviations used: CSF, cerebrospinal fluid; IB4, isolectin B4; MBP, myelin basic protein; MG, microglia; MOG, myelin oligodendrocyte glycoprotein; NPC, neural progenitor cell; Q-PCR, quantitative real-time PCR.

Conflict of interest: The authors have declared that no conflict of interest exists. Citation for this article: J. Clin. Invest. 116:905-915 (2006). doi:10.1172/JCI26836. survival of neurons (11) and oligodendrocytes (10) and interferes with repair processes (12), a local immune response that is properly controlled can support survival and promote remyelination (13) and recovery $(14,15)$. It was further shown that after an injury to the CNS, a local immune response that is well controlled in time, space, and intensity by peripheral adaptive immune processes (mediated by $\mathrm{CD}^{+}$helper $\mathrm{T}$ cells directed against autoantigens residing at the site of the lesion) is a critical requirement for posttraumatic neuronal survival and repair $(14,16-19)$. These and other results led our group to formulate the concept of "protective autoimmunity" (16).

The positive effect of the helper T cells is mediated, at least in part, through their dialog with MG, key players in the immune system's innate arm. Among the compounds produced by these autoimmune $\mathrm{T}$ cells in their role as key players in the adaptive arm of the immune system is IFN- $\gamma$, a characteristic Th1 (proinflammatory) cytokine which, when present in moderate amounts, has a beneficial effect on neural tissues (19-21). Thus, whereas survival of neurons is supported by MG that encounter IFN- $\gamma$ in well-controlled amounts, uncontrolled amounts of IFN- $\gamma$ interfere with neural survival (19). These positive microglial effects do not negate the existence of destructive MG, whose inactivation might have a beneficial effect on the diseased brain (7). They do, however, argue in favor of the need for MG whose activity is well controlled and is thus supportive of CNS tissue maintenance and repair.

On the basis of our findings, we suggest that 1 of 2 possible fates awaits MG encountering IFN- $\gamma$ : MG exposed to low concentrations of this cytokine exhibit an immune-mediated healing response, whereas those exposed to high IFN- $\gamma$ concentrations respond by causing an immune-mediated demyelinating disease $(5,6)$; or autoimmune $T$ cells that express the characteristic Th2 (antiinflammatory) cytokine IL-4 over a wide range of concentrations activate MG to support neuronal survival (19).

Here we examined whether IL-4, via modulation of MG both in vitro and in vivo, could overcome the destructive effects of highdose IFN- $\gamma$, known to be associated with EAE. In vitro, a high dose 
A GFP/NG2/RIP
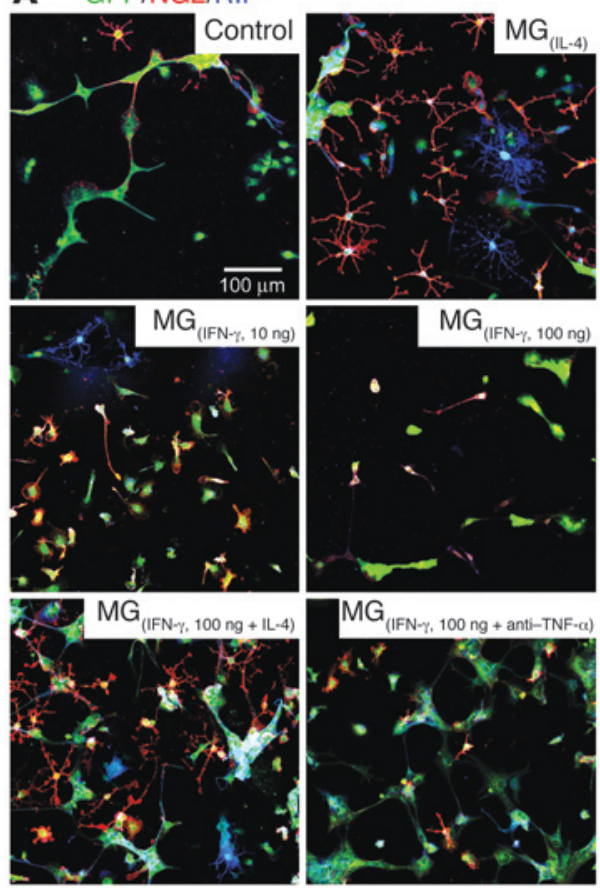

\section{B}

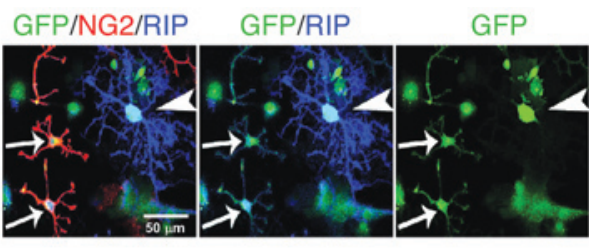

c

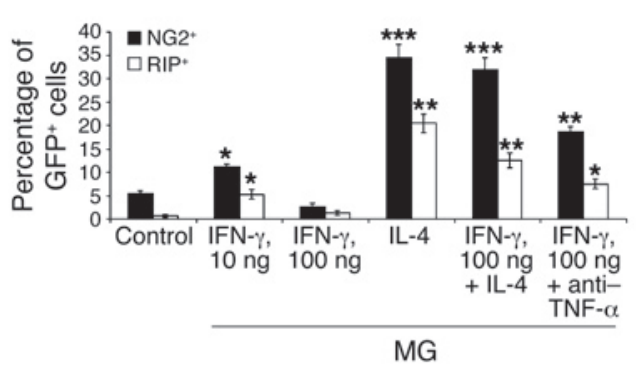

or IL-4 $(10 \mathrm{ng} / \mathrm{ml})$ together with IFN- $\gamma(100 \mathrm{ng} / \mathrm{ml})$. After the growth media and cytokine residues were washed off, each of the treated microglial preparations was freshly cocultured with dissociated NPC spheres on coverslips coated with Matrigel in the presence of differentiation medium. We used NPCs expressing GFP to verify that any differentiation of oligodendrocytes seen in the culture was derived from the NPCs rather than from contamination of the primary microglial culture. After 10 days we could discern both GFP-expressing NPCs colabeled with the oligodendrocyte progenitor marker NG2 and RIPstained mature oligodendrocytes at the pre-ensheathing stage (22) (Figure 1). A few $\mathrm{GFP}^{+} / \mathrm{NG}^{+}$and $\mathrm{GFP}^{+} / \mathrm{RIP}^{+}$cells were seen in control NPCs cultured without MG and in NPCs cocultured with MG pretreated with the low dose of IFN- $\gamma\left[\mathrm{MG}_{(\mathrm{IFN}-\gamma, 10 \mathrm{ng})}\right]$. In cocultures of NPCs with $\mathrm{MG}_{(\mathrm{IL}-4)}$, however, the increase in number of $\mathrm{GFP}^{+} / \mathrm{NG}^{+}$ and $\mathrm{GFP}^{+} / \mathrm{RIP}^{+}$cells was dramatic. In contrast to the low dose of IFN- $\gamma$, treatment with $100 \mathrm{ng} / \mathrm{ml} \mathrm{IFN- \gamma}$ caused MG to block oligodendrogenesis from the cocultured NPCs. Interestingly, the addition of IL-4 to $M G$ treated with $100 \mathrm{ng} / \mathrm{ml}$ IFN- $\gamma$ overcame the adverse effect of high-dose IFN- $\gamma$, with the result that these MG were able to induce

of IFN- $\gamma$, but not a low dose, impaired the ability of MG to support oligodendrogenesis from adult neural stem cells and neural progenitor cells (NPCs). IL-4 counteracted the interference with oligodendrogenesis caused by high IFN- $\gamma$ concentrations. When IL-4-activated MG were stereotaxically injected through the cerebral ventricles into the cerebrospinal fluid (CSF) of rats with acute EAE or of mice with a remitting-relapsing autoimmune disease, the animals demonstrated significantly more oligodendrogenesis and significantly less neurological deficit than did their vehicleinjected diseased controls.

\section{Results}

Effects of MG on oligodendrogenesis in vitro: the dual effect of IFN- $\gamma$. Recent studies from our laboratory showed that IL-4 induces MG to secrete IGF-I and suppresses their production of TNF- $\alpha$ (19). In the present study we first examined whether MG that encounter a high dose of IFN- $\gamma$ adopt a phenotype that interferes with oligodendrogenesis from NPCs, and if so, whether IL-4 can counteract this negative effect.

We first examined the effects on NPCs of MG that were preincubated for 24 hours in their optimal growth media (19), in the presence or absence of the cytokines IL-4 $(10 \mathrm{ng} / \mathrm{ml}), \operatorname{IFN}-\gamma(10$ or $100 \mathrm{ng} / \mathrm{ml})$,
NPCs to differentiate into oligodendrocytes. When we added neutralizing anti-TNF- $\alpha$ antibodies to $\mathrm{MG}_{(\mathrm{IFN}-\gamma, 100 \mathrm{ng} / \mathrm{ml}) \text {, we observed a }}$ significant increase in the numbers of $\mathrm{NG}^{+}$and (to a lesser extent) $\mathrm{RIP}^{+}$cells in NPCs cocultured with those MG. Anti-TNF- $\alpha$ had no effect on cocultures of NPCs with $\mathrm{MG}_{(\mathrm{IL}-4)}$ (Figure $\left.1 \mathrm{~A}\right)$. In a previous study by our group, addition of anti-IGF-I antibodies to cocultures of NPCs with $\mathrm{MG}_{(\mathrm{IL}-4)}$ blocked oligodendrogenesis (23), indicating that oligodendrogenesis from NPCs induced by $\mathrm{MG}_{(\mathrm{IL}-4)}$ is mediated by IGF-I. Notably, the newly differentiated oligodendrocytes were more branched in the presence of $\mathrm{MG}_{(\mathrm{IL}-4)}$ than in the presence of $\mathrm{MG}_{(\mathrm{IFN}-\gamma, 10 \mathrm{ng})}$ (Figure $\left.1 \mathrm{~A}\right)$. In each of the cocultures, all NG2 ${ }^{+}$and $\mathrm{RIP}^{+}$cells were also found to be colabeled with GFP (Figure 1B). Some $\mathrm{GFP}^{+} / \mathrm{NG}^{+}$cells coexpressed $\mathrm{RIP}^{+}$, whereas well-branched mature oligodendrocytes $\left(\mathrm{GFP}^{+} / \mathrm{RIP}^{+}\right)$did not express NG2 at this stage (Figure 1B). Quantitative analysis verified that IL-4 and (to a lesser extent) anti-TNF- $\alpha$ had overcome the inhibitory effect of $\mathrm{MG}_{(\mathrm{IFN}-\gamma, 100 \mathrm{ng})}$ on oligodendrogenesis induction (Figure 1C). The effect of nonactivated MG in these experiments was neither destructive nor supportive.

To examine the correlation between the production of IGF-I and the ability of $\mathrm{MG}_{(\mathrm{IL}-4)}$ to overcome the impediment to oligodendrogenesis, and to determine how this relationship is influenced 
A

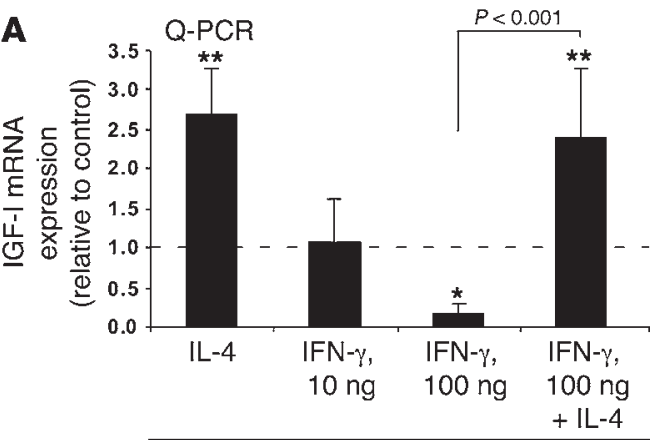

MG

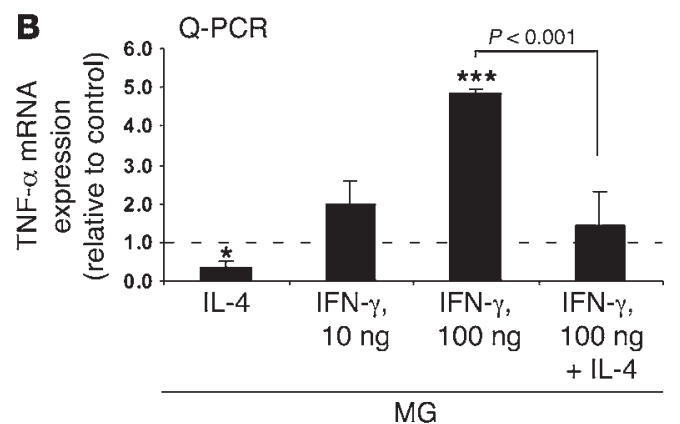

MG

by TNF- $\alpha$ production, we carried out quantitative real-time PCR (Q-PCR) analyses (Figure 2). The results showed that low-dose IFN- $\gamma$ had no effect on the expression of IGF-I, whereas high-dose

\section{Figure 2}

IL-4 partially reverses downregulation of IGF-I expression and upregulation of $T N F-\alpha$ expression in MG activated by $100 \mathrm{ng} / \mathrm{ml} \mathrm{IFN-} \gamma$. (A) Q-PCR of MG identical to those described in Figure 124 hours after treatment. A significant increase in IGF-I was seen in MG activated by $10 \mathrm{ng} / \mathrm{ml} \mathrm{IL-4}$. (B) TNF- $\alpha$ transcripts in MG activated by $100 \mathrm{ng} / \mathrm{ml}$ IFN- $\gamma$ concomitantly with $10 \mathrm{ng} / \mathrm{ml}$ IL-4 compared with IFN- $\gamma$-activated MG. Values represent the relative amounts of amplified mRNA normalized against $\beta$-actin and are expressed as fold of induction relative to untreated control MG (dashed line). Data are from 2 independent experiments in replicate cultures; bars represent mean $\pm \mathrm{SD}$. ${ }^{*} P<0.05$, ${ }^{* *} P<0.01,{ }^{* \star} P<0.001$ versus control; ANOVA.

IFN- $\gamma$ completely arrested it. In contrast, IL- 4 had a robust effect on IGF-I expression and could overcome the negative effect of high-dose IFN- $\gamma$ on IGF-I (Figure 2A). In addition, whereas highdose IFN- $\gamma$ induced TNF- $\alpha$ production, IL-4 arrested it (Figure $2 \mathrm{~B}$ ), possibly explaining the ability of IL-4 to overcome the negative effect of high-dose IFN- $\gamma$ on IGF-I.

$M G_{(I L-4)}$ induce oligodendrogenesis from endogenous neural stem cells and NPCs in an acute EAE model. The finding that $\mathrm{MG}_{(\mathrm{IL}-4)}$ in vitro created conditions favoring differentiation of NPCs into oligodendrocytes and overcame the negative effect of $\mathrm{MG}_{(\mathrm{IFN}-\gamma, 100 \mathrm{ng})}$ on oligodendrogenesis encouraged us to investigate whether $\mathrm{MG}_{(\mathrm{IL}-4)}$ would promote oligodendrogenesis from endogenous adult NPCs $(2,24)$ in animals with acute or chronic EAE. To examine this possibility we first induced acute EAE in adult Lewis rats $(n=8)$ by immunizing them with myelin basic protein (MBP)

\section{Figure 3}

Intraventricularly injected $\mathrm{MG}_{(\mathrm{IL}-4)}$ significantly improves the clinical symptoms of acute EAE and induces oligodendrogenesis in rats. On day 7 after MBP vaccination, rat brain lateral ventricles were stereotaxically injected bilaterally with PBS or with syngeneic $\mathrm{MG}_{(\mathrm{IL}-4)}(n=8$ per group). From day 14, BrdU was injected for 2.5 days. Naive rats received the same course of BrdU injection $(n=4)$. Spinal cords were excised 7 days after the first BrdU injection (21 days after immunization). (A) EAE scores in rats treated either with $\mathrm{MG}_{(\mathrm{IL}-4)}$ or with $\mathrm{PBS}(n=8$ per group). Data are mean \pm SEM. ${ }^{* *} P<0.001$; Student's $t$ test. (B) EAE scores of individual rats 14 and 16 days after vaccination. (C) $\mathrm{NG}_{2}{ }^{+}$or $\mathrm{RIP}^{+}$cells colabeled with $\mathrm{BrdU}^{+}$cells were quantitatively analyzed both in gray matter (GM) and in white matter (WM) at 300- $\mu \mathrm{m}$ intervals along longitudinal $30-\mu \mathrm{m}$ sagittal sections of spinal cord (T8-T9; $n=6-8$ per group). Data are mean \pm SEM. ${ }^{*} P<0.05,{ }^{* *} P<0.01$, ${ }^{* * \star} P<0.001$ versus naive; ANOVA. (D) Representative confocal images of an area taken from the white matter of an $\mathrm{MG}_{(\mathrm{IL}-4)}$-treated rat. Newly formed oligodendrocytes were identifiable by colocalization of BrdU and NG2 or RIP (arrows). Separate confocal channels are shown in 2 right panels.

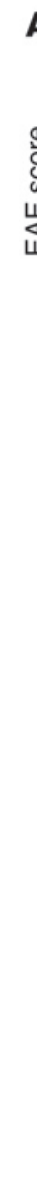

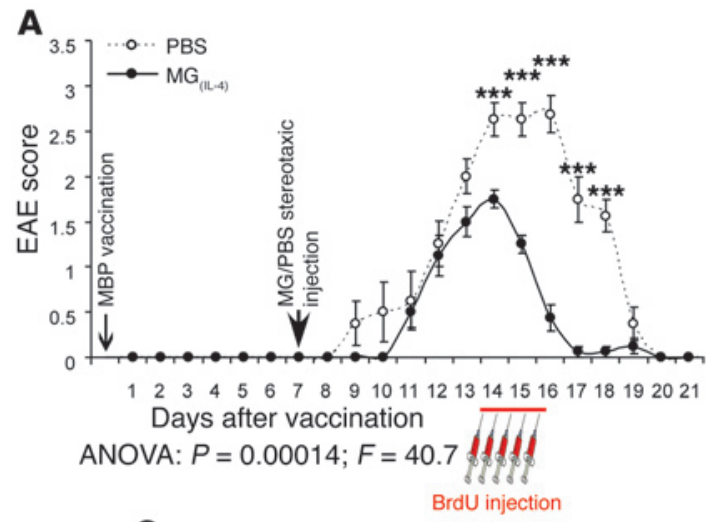
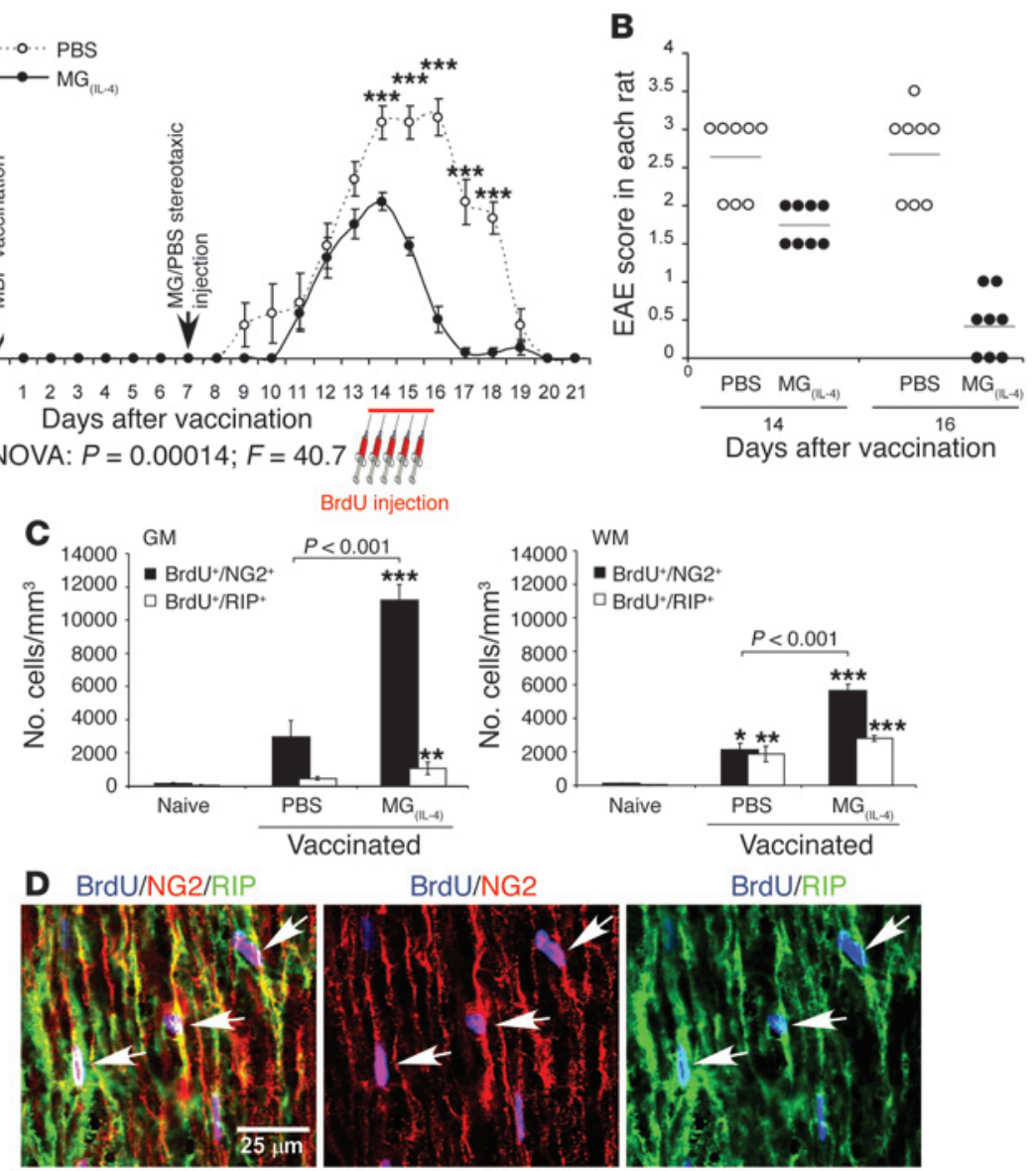
A

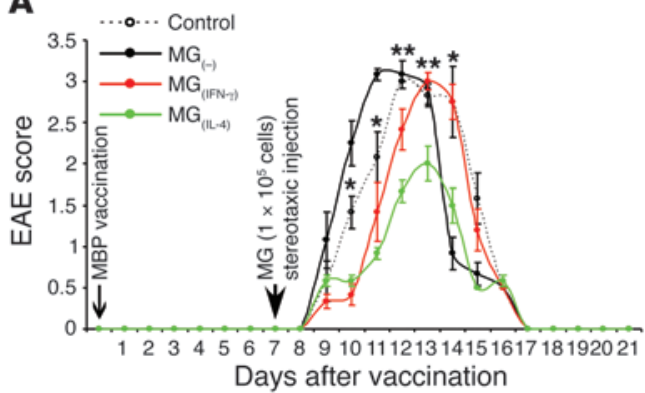

B

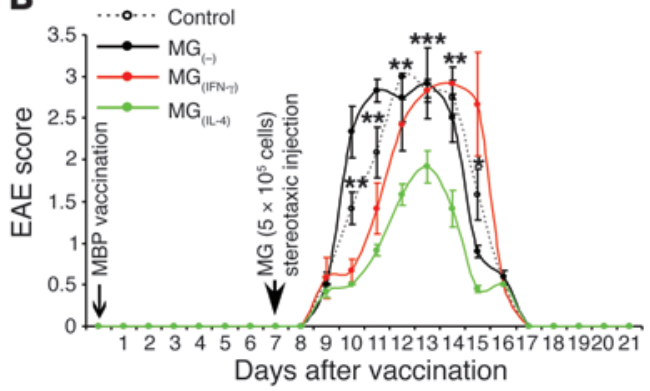

emulsified in CFA. Seven days later we introduced $10 \mathrm{ng} / \mathrm{ml}$ $\mathrm{MG}_{(\mathrm{IL}-4)}$ into the CSF of these rats via stereotaxic bilateral injection into their cerebral ventricles. Control rats $(n=8)$ were similarly injected with PBS. Seven days after injection of $\mathrm{MG}_{(\mathrm{IL}-4)}$ or PBS, the rats were injected i.p. with BrdU every 12 hours for 2.5 days to identify proliferating cells, and 21 days after the MBP vaccination their spinal cords were examined for the appearance of newly formed oligodendrocytes.

Although the symptoms of paralysis observed in this model of acute EAE do not result from demyelination, they are beneficially affected by IL-4 (25-27). We therefore postulated that not only oligodendrogenesis but also functional integrity would benefit from $\mathrm{MG}_{(\mathrm{IL}-4)}$, possibly in part through the IGF-I that these MG produce $(19,23)$. Follow-up of the clinical manifestations of EAE with and without microglial treatment showed that after injection with $\mathrm{MG}_{(\mathrm{IL}-4)}$, the onset of EAE symptoms was delayed and the severity and duration of clinical paralysis were significantly reduced (Figure 3, $A$ and B). Similar results were obtained in an independent experiment carried out in the absence of BrdU, indicating that BrdU did not affect the manifestation of disease or the treatment efficacy. Because the clinical symptoms of EAE in this model are manifested by tail and hind limb paralysis, we assessed oligodendrogenesis in

\section{Figure 4}

Effect of MG on the clinical course of EAE depends on their number and activity. On day 7 after induction of EAE in rats as described in Figure 3 , their brain lateral ventricles were stereotaxically injected bilaterally with syngeneic $\mathrm{MG}_{(-)}, \mathrm{MG}_{(\mathrm{IFN}-\gamma)}$, or $\mathrm{MG}_{(\mathrm{LL}-4)}(n=6$ per group). One group of rats with EAE remained untreated and served as a control $(n=6)$. From day 10, BrdU was injected for 2.5 days. Spinal cords were excised 11 days after the first BrdU injection, by which time disease in the rats of all groups was resolved. (A) EAE scores in rats injected stereotaxically with low-dose $\left(1 \times 10^{5}\right.$ cells in $5 \mu \mathrm{l}$ PBS for 5 minutes) of differently activated MG. (B) EAE scores in rats injected stereotaxically with high doses $\left(5 \times 10^{5}\right.$ cells in $5 \mu$ I PBS for 5 minutes). Data are mean \pm SEM. ${ }^{*} P<0.05,{ }^{* *} P<0.01,{ }^{* * *} P<0.001, \mathrm{MG}_{(\mathrm{LL}-4)}$ versus control; Student's $t$ test. Significant differences (2-factor repeated measures ANOVA) were found between the $\mathrm{MG}_{(-)}$and $\mathrm{MG}_{(\mathrm{LL}-4)}$ groups: (A) $P=0.0001, F=61.1$; (B) $P=0.0001, F=79.4$.

the spinal cords of these rats. Spinal cords were excised, and longitudinal sections from the T8-T9 region were analyzed for newly formed oligodendrocytes and MG. In both the untreated $\left[\mathrm{MG}_{(-)}\right]$ and the $\mathrm{MG}_{(\mathrm{IL}-4)}$-treated groups of rats with EAE we detected cells that were triple-labeled for BrdU (proliferating cells), NG2, and RIP. Some of the proliferating cells in both the gray and the white matter of $\mathrm{MG}_{(\mathrm{IL}-4)}$-treated rats were $\mathrm{BrdU}^{+} / \mathrm{NG}^{+} / \mathrm{RIP}^{+}$, indicating that they had differentiated into committed oligodendrocytes. In those rats there were significantly more $\mathrm{BrdU}^{+} / \mathrm{NG}^{+}$cells in the gray matter and significantly more $\mathrm{BrdU}^{+} / \mathrm{RIP}^{+}$cells in the white matter than in PBS-treated rats (Figure $3 \mathrm{C}$ ). Some oligodendrogenesis was observed in rats with EAE that were injected with PBS, leading us to consider the possibility that such oligodendrogenesis represents a self-reparative mechanism of myelin renewal that is induced by the inflammatory conditions even in the absence of any intervention [such as injection of $\left.\mathrm{MG}_{(\mathrm{IL}-4)}\right]$. Examination showed that the amount of oligodendrogenesis occurring in naive rats was very small; thus in the absence of treatment, oligodendrogenesis in rats with EAE that were injected with PBS was more abundant than in naive rats and was further increased by $\mathrm{MG}_{(\mathrm{IL}-4)}$ (Figure $3 \mathrm{C}$ ). Coexpression of NG2 and RIP in the $\mathrm{BrdU}^{+}$cells confirmed that the newly formed cells were oligodendrocytes (Figure 3D). It should be noted that BrdU in these experiments was injected at the peak of the disease, a stage at which a spontaneous mechanism that limits the proinflammatory response is likely to be operating, with consequent reduction in the number of Th1 cells and/or the appearance of Th2 cells. It is therefore possible that the oligodendrogenesis seen in rats with EAE was triggered as a result of this decline in number of Th1 cells or a spontaneous increase in number of Th2 cells or both (28).

\section{Figure 5}

Dose dependency of oligodendrogenesis induced in $\mathrm{MG}_{(\mathrm{IL}-4)}$-injected rats. $\mathrm{NG}^{+}$or RIP+ cells colabeled with $\mathrm{BrdU}^{+}$cells were quantitatively analyzed in (A) gray matter and (B) white matter at $300-\mu \mathrm{m}$ intervals along longitudinal $30-\mu \mathrm{m}$ sagittal sections of spinal cord (T8-T9) from MBP-vaccinated rats injected with low- or high-dose $\mathrm{MG}_{(\mathrm{IL}-4)}(n=5-6$ per group) as indicated. Data are expressed as mean \pm SEM. ${ }^{* \star} P<0.01,{ }^{\star \star \star} P<0.001$ versus control; ANOVA).
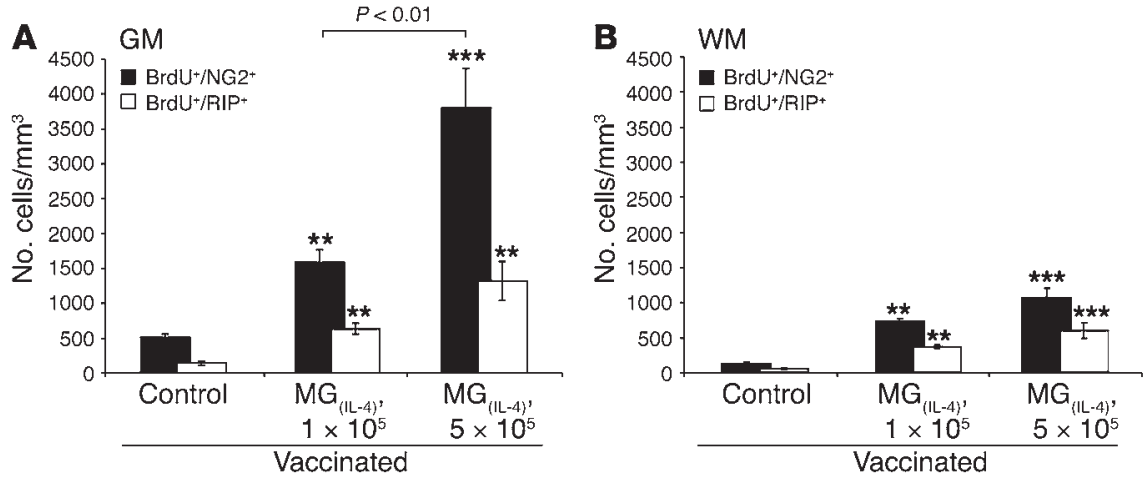

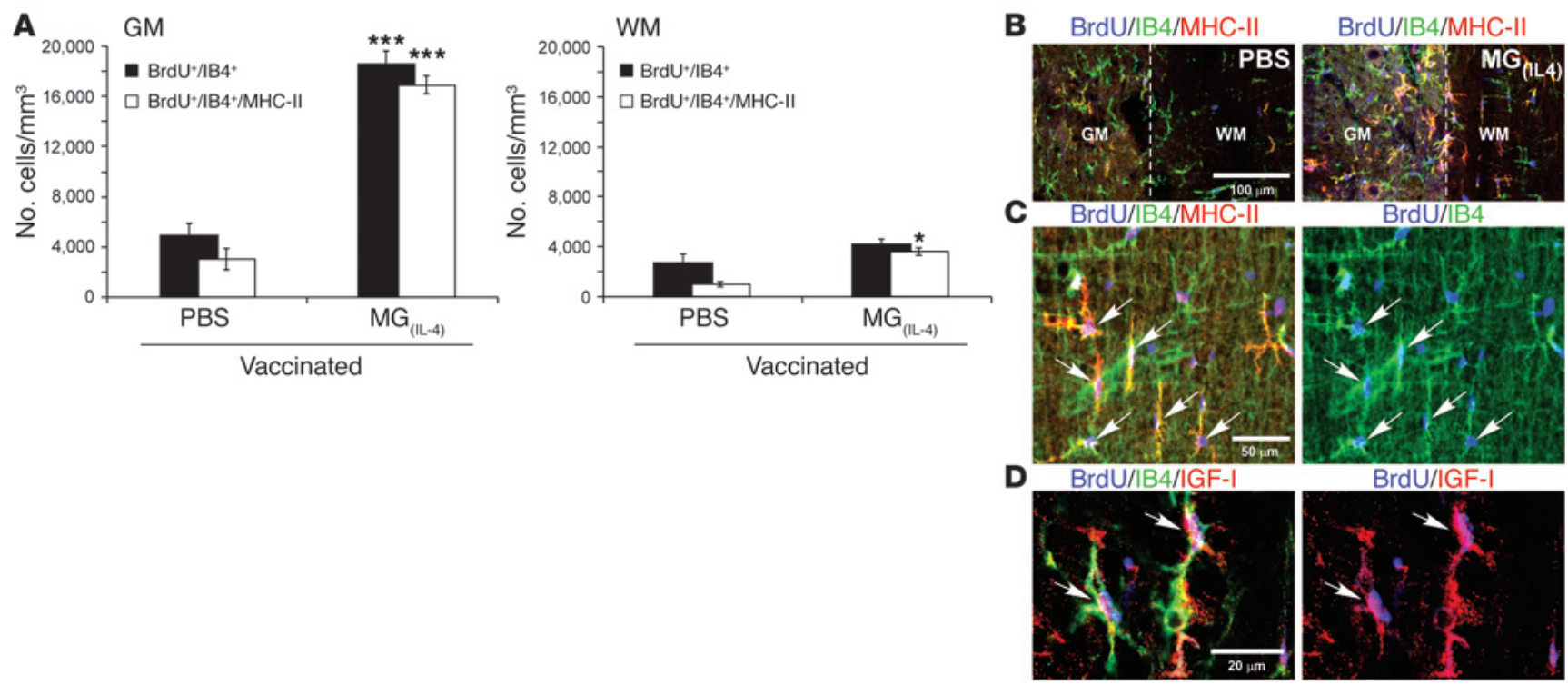

\section{Figure 6}

Rats injected intraventricularly with $\mathrm{MG}_{(\mathrm{IL}-4)}$ exhibit increased microglial proliferation and MHC class II (MHC-II) expression. The spinal cords analyzed in Figure 3 were also examined for microgliogenesis. (A) Quantitative analysis of IB4 ${ }^{+}$and IB4 $/ \mathrm{MHC}$ class II+ cells colabeled with $\mathrm{BrdU}^{+}$(mean $\pm \mathrm{SEM}$ ) from both gray matter and white matter ( $n=8$ per group). ${ }^{*} P<0.05,{ }^{* \star *} P<0.001$ versus PBS; 2 -tailed Student's $t$ test. (B) Representative confocal microscopy of longitudinal sagittal sections of spinal cords (T8-T9) stained with BrdU and costained with IB4 for MG and $\mathrm{MHC}$ class II 21 days after injection with PBS or with $\mathrm{MG}_{(\mathrm{IL}-4)}$. The most abundant populations of BrdU+ cells were immunoreactive to IB4 in both control and $\mathrm{MG}_{(\mathrm{IL}-4)^{-}}$-injected rats. Significantly more $\mathrm{MHC}$ class $\mathrm{II}^{+}$cells were seen, especially in the gray matter, in slices from $\mathrm{MG}_{(\mathrm{IL}-4)^{-}}$ injected rats than from those of PBS-injected control rats. Note that the images are from areas that include both gray matter and white matter; dashed line shows the border between the 2 areas. (C and D) Most of the newly formed MG (IB4+/BrdU + ) in MG $_{(\mathrm{IL}-4)}$-treated rats coexpressed (C) MHC class II and (D) IGF-I (arrows).

These findings prompted us to examine whether the observed effect of $\mathrm{MG}_{(\mathrm{IL}-4)}$ in vivo depends on the number of injected cells and whether IFN- $\gamma$-activated MG would have any effect. To examine the effects of different amounts of the differently activated MG on the clinical course of EAE, we carried out the experiment described in Figure 4. Included in that experiment were groups of rats with EAE that were injected with $\mathrm{MG}_{(-)}$, $\mathrm{MG}_{(\mathrm{IFN}-\gamma)}$, or $\mathrm{MG}_{(\mathrm{IL}-4)}$ at 1 of the 2 tested cell dosages $\left(1 \times 10^{5}\right.$ or $5 \times 10^{5}$ cells) and a group of noninjected control rats with EAE. As shown, $\mathrm{MG}_{(\mathrm{IFN}-\gamma)}$ did not exacerbate the clinical manifestations at either dosage (Figure 4, A and B), and at the lower dosage it even had a small beneficial effect in that it delayed the onset of the disease relative to untreated (control) animals with EAE $(P=0.0045, F=14.16$; ANOVA; Figure $4 \mathrm{~A}) . \mathrm{MG}_{(-)}$at both dosages had no significant effect either on symptom severity or on disease onset. Treatment with $\mathrm{MG}_{(\mathrm{IL}-4)}$ was equally beneficial at both tested dosages (Figure 4, A and B). With the object of utilizing the same animals for both clinical and cellular analysis, we injected all rats in the above experiments with BrdU. In the experiment described in Figure 4 we administered the first BrdU injection 10 days after the immunization with MBP/CFA, and not after 14 days as in the experiment described in Figure 3. This was done to enable us to detect a possible earlier effect of $\mathrm{MG}_{(\mathrm{IL}-4)}$ on oligodendrogenesis than that observed in the earlier experiment. As shown in Figure 5, A and B, treatment with $\mathrm{MG}_{(\mathrm{IL}-4)}$ yielded an increase in oligodendrogenesis even when the latter was assessed as early as 3 days after MG were administered (which coincided with the time point at which BrdU was injected). Moreover, a stronger effect was obtained with the higher
$\mathrm{MG}_{(\mathrm{IL}-4)}$ dosage, indicating its dose dependence. Comparison of the effect of low-dose $\mathrm{MG}_{(\mathrm{IL}-4)}$ in this experiment to the effect shown with the same dose in Figure 3 revealed differences between them in the ratios of newly formed mature $\left(\mathrm{BrdU}^{+} / \mathrm{RIP}^{+}\right)$ oligodendrocytes both in the white matter and in the gray matter. These differences might be attributable to differences in timing of the BrdU injection.

According to the traditional view, MG that express MHC class II molecules are the activated MG that are present in inflammation-associated diseases (29-31). Recent studies, however, by our group and by others, showed that not all MHC class II-expressing MG are destructive $(19,32)$. For example, MHC class II-expressing MG that are activated by low-dose IFN- $\gamma$ or by IL- 4 support cell survival (19). Analysis of consecutive sections obtained from the rats described in Figure 3 revealed the presence of newly formed MG in rats with EAE that were treated with both PBS and $\mathrm{MG}_{(\mathrm{IL}-4)}$, with the highest accumulation seen in the gray matter of the $\mathrm{MG}_{(\mathrm{IL}-4)}$-treated rats (Figure 6A). No newly formed $\mathrm{MG}$ were seen in naive rats. Analysis of newly formed MG (BrdU- and isolectin B4-positive; $\left.\mathrm{BrdU}^{+} / \mathrm{IB}^{+}\right)$in the gray matter of both PBS-treated and $\mathrm{MG}_{(\mathrm{IL}-4)}$-treated rats revealed that most of these new $\mathrm{MG}$ were $\mathrm{MHC}$ class $\mathrm{II}^{+}$, and that they were significantly more numerous in the rats treated with $\mathrm{MG}_{(\mathrm{IL}-4)}$ than in the PBS-treated rats (Figure 6, $A$ and $B)$. Confocal scanning microscopy confirmed the expression of $\mathrm{MHC}$ class II by the newly formed MG $\left(\mathrm{BrdU}^{+} / \mathrm{IB}^{+}\right)$in the white matter of $\mathrm{MG}_{(\mathrm{IL}-4)}$-treated rats (Figure $6 \mathrm{C}$ ).

Because MG can be induced to express IGF-I (19), and because the MG in this study induced oligodendrogenesis in vitro (Figure 1) and overcame the strongly proinflammatory conditions mediated 
A

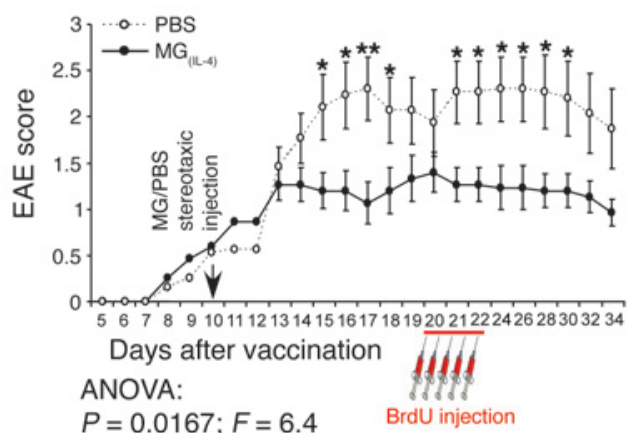

D

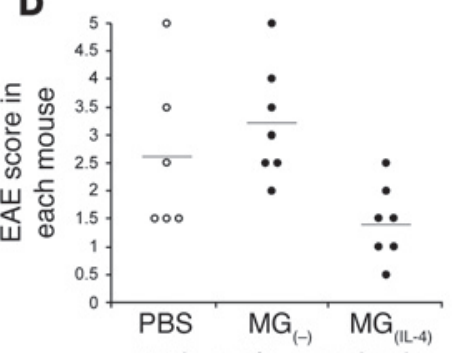

17 days after vaccination
B

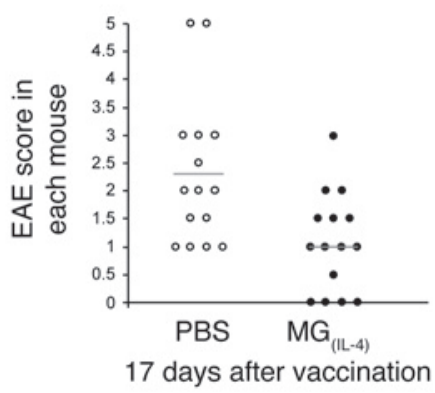

C

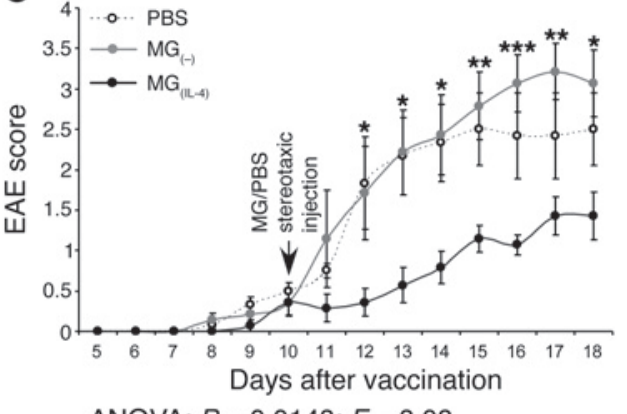

ANOVA: $P=0.0148 ; F=8.08$

\section{E}
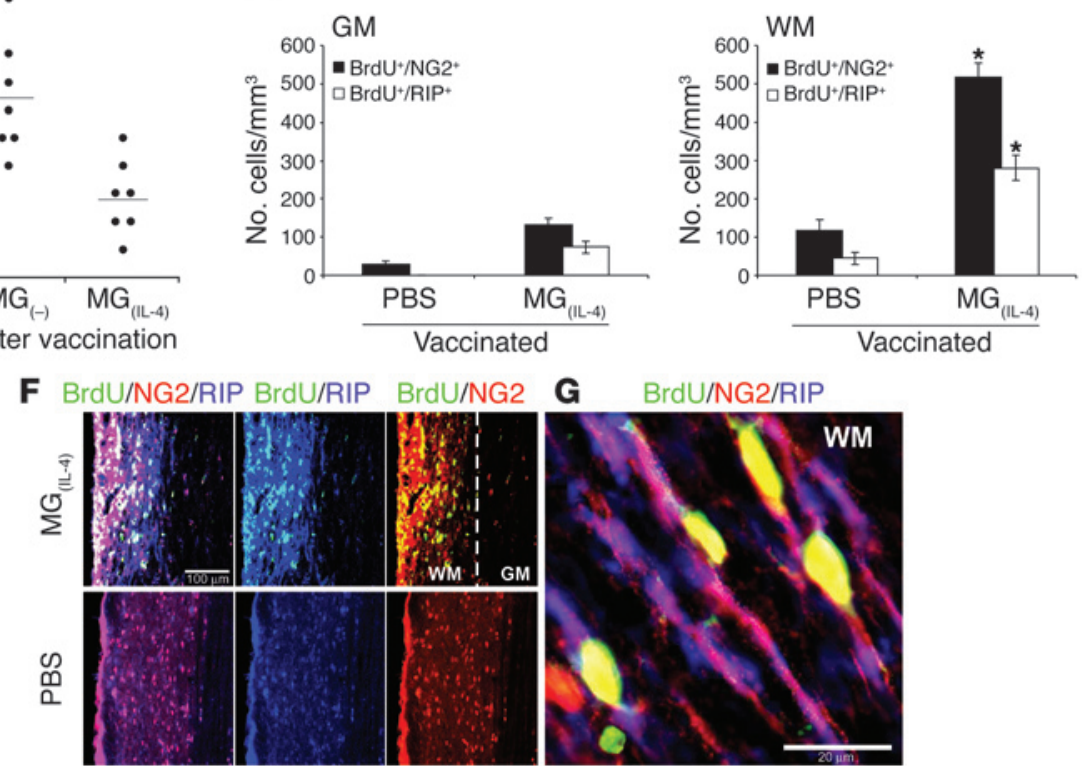

\section{Figure 7}

In mice with chronic $\mathrm{EAE}$, intraventricularly injected $\mathrm{MG}_{(\mathrm{IL}-4)}$ significantly improves clinical features and induces oligodendrogenesis. Spinal cords were excised 12 days after the last BrdU injection. (A and B) EAE scores in mice injected with either $\mathrm{MG}_{(\mathrm{IL}-4)}$ or PBS $\left(n=15\right.$ per group). ${ }^{*} P<0.05$, ${ }^{* *} P<0.01$; Student's $t$ test. (C and D) Lack of beneficial effect of $M_{G_{(-)}}$. In an independent experiment, mice with $E A E$ were injected with $M G_{(L-4)}$ $(n=7), \mathrm{MG}_{(-)}(n=7)$, or PBS $(n=6)$ on day 10 after MOG vaccination. ${ }^{*} P<0.05,{ }^{* \star} P<0.01,{ }^{* * *} P<0.001$, MG $\mathrm{MG}_{(-)}$versus $\mathrm{MG}_{(\mathrm{IL}-4)}$; Student's $t$ test. ANOVA revealed no significant effect of $M_{(-)}$injection relative to $P B S$ injection, whereas $M G_{(L-4)}$ had a significant effect. Shown are (A and $\left.\mathbf{C}\right)$ mean \pm SEM and (B and D) individual EAE scores on day 17. (E) NG2+ and RIP+ cells colabeled with BrdU+ cells were quantitatively analyzed at 300- $\mu \mathrm{m}$ intervals in both gray matter and white matter of the spinal cord ( $n=4$ per group). Data are mean \pm SEM. ${ }^{\star} P<0.05$ versus PBS; 2-tailed Student's $t$ test. $(F)$ Representative confocal images of longitudinal sections of spinal cords stained with BrdU and costained for NG2 and RIP 34 days after immunization in $\mathrm{MG}_{(\mathrm{LL}-4)^{-}}$and PBS-treated mice. Separate confocal channels are shown in 2 right panels. (G) Newly formed oligodendrocytes were identifiable by colocalization of BrdU, NG2, and RIP in the white matter of $\mathrm{MG}_{(\mathrm{IL}-4)}$-treated mice.

by high-dose IFN- $\gamma$, we sought to identify IGF-I-expressing MG in the spinal cords of $\mathrm{MG}_{(\mathrm{IL}-4)}$-treated rats. Newly formed $\mathrm{BrdU}^{+} / \mathrm{IB}^{+}$ MG were found to express IGF-I (Figure 6D). Not all MHC class $\mathrm{II}^{+} /$ IGF-I $\mathrm{I}^{+} \mathrm{MG}$ were $\mathrm{BrdU}^{+}$, however, suggesting that those cells might be either the injected MG or the newly formed ones.

$M G_{(I L-4)}$ induce oligodendrogenesis from endogenous neural stem cells and $N P C$ in a model of chronic EAE. To determine whether $\mathrm{MG}_{(\mathrm{IL}-4)}$ is also beneficial in a mouse model of chronic EAE, we compared mice treated with $\mathrm{MG}_{(\mathrm{IL}-4)}$ and with PBS. EAE was induced in C57BL/6J mice by immunization with the encephalitogenic myelin oligodendrocyte glycoprotein (MOG) peptide 35-55 (MOG $35-55)$ emulsified in incomplete Freund's adjuvant containing Mycobacterium tuberculosis and Bordetella pertussis toxin (33). Ten days after EAE induction we injected $\mathrm{MG}_{(\mathrm{IL}-4)}$ or PBS into the CSF via bilateral stereotaxic injection into the cerebral ventricles. BrdU was injected for 2.5 days, starting at day 20. The 2 groups of injected mice differed significantly both in the severity of paralysis (Figure 7A) and in the number of mice expressing the disease (Figure 7B). To verify that the effect of $\mathrm{MG}_{(\mathrm{IL}-4)}$ was due to their activation, we repeated the experiment and tested an additional group of mice in which EAE was induced and $\mathrm{MG}_{(-)}$were injected into the cerebral ventricles as described for Figure 7. As in the case of the rats with EAE (Figure 4), the injected $\mathrm{MG}_{(-)}$did not have any beneficial effect; if at all, they had an adverse effect - albeit not statistically significant - compared with PBS-injected mice with EAE (Figure 7, C and D). In the white matter (but not in the gray matter) of mice with EAE, signifi- 

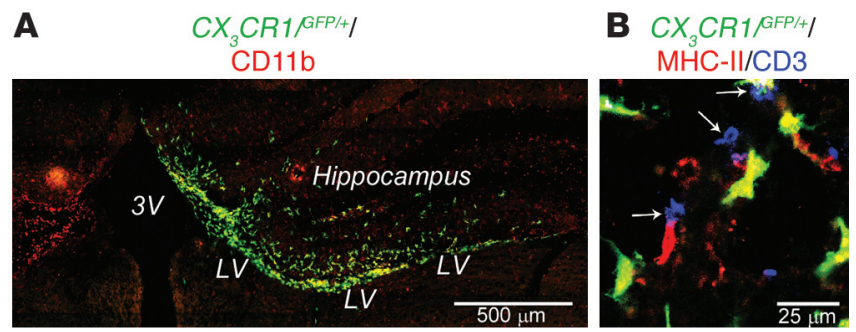

Figure 8

Distribution of $C X_{3} C R 1 / G F P /+M G 9$ days after stereotaxic injection. (A) Localization of GFP+ cells colabeled with the microglial marker CD11b in the right lateral ventricle (LV) after injection of $\mathrm{MG}_{(\mathrm{IL}-4)}$ from $C X_{3} C R 1 / G F P /++$ mice into mice with EAE. Note the hippocampal area in the $\mathrm{MG}_{(\mathrm{IL}-4)}$-injected mice was heavily populated by $\mathrm{MG}_{(\mathrm{LL}-4)}$-GFP+ ${ }^{+}$cells. (B) $\mathrm{MG}_{(\mathrm{IL}-4)}-\mathrm{GFP}^{+}$cells coexpressing MHC class II populated the spinal cord at level T8-T9 adjacent to the ependyma of the central canal associated with $\mathrm{CD}^{+}$cells (arrows). $3 \mathrm{~V}$, third ventricle.

cantly more newly formed oligodendrocytes $\left(\mathrm{BrdU}^{+} / \mathrm{NG}^{+} / \mathrm{RIP}^{+}\right)$ were observed in the group treated with $\mathrm{MG}_{(\mathrm{IL}-4)}$ than in the PBStreated group (Figure 7, E and F). In contrast to PBS-treated rats with monophasic (acute) EAE, hardly any oligodendrogenesis could be seen in their counterparts in which EAE was chronic or in naive mice (data not shown), suggesting that chronic conditions do not favor oligodendrogenesis. With the aid of scanning confocal microscopy, coexpression of NG2 and RIP by the newly formed oligodendrocytes was confirmed in the white matter of the $\mathrm{MG}_{(\mathrm{IL}-4)^{-}}$ treated mice with chronic EAE (Figure 7G).

To follow the fate of the injected MG and trace their local interaction with T cells, we prepared MG from newborn knock-in mice in which 1 copy of the gene encoding the chemokine receptor $\mathrm{CX}_{3} \mathrm{CR} 1$ had been replaced with GFP reporter cDNA (34). GFP expression in these mice is under the control of the $\mathrm{CX}_{3} \mathrm{CR} 1$ promoter, and consequently heterozygous $\left(C X_{3} C R 1 /{ }^{G F P /+}\right)$ mice express both the receptor and GFP on CNS MG, peripheral monocytes, and a subset of mononuclear phagocytes that includes macrophages and dendritic cells $(35,36)$. Seven days after the vaccination, C57BL/6J mice with chronic EAE received unilateral stereotaxic injections of $\mathrm{MG}_{(-)}$or $\mathrm{MG}_{(\mathrm{IL}-4)}$ from syngeneic $C X_{3} C R 1 /{ }^{G F P /+}$ mice $\left(1 \times 10^{5}\right.$ cells in $3 \mu$ l PBS for 3 minutes $)$ into the CSF via the right brain lateral ventricles (Bregma, $-0.4 ; \mathrm{L}, 0.8 ; \mathrm{V}, 2.5$ ). On examination $\mathrm{GFP}^{+}$cells coexpressing $\mathrm{MHC}$ class II were detected adjacent to $\mathrm{T}$ cells $\left(\mathrm{CD}^{+}\right)$along the ventricle approaching the spinal cord. Figure 8 depicts the distribution of $\mathrm{MG}_{(\mathrm{IL}-4)}-\mathrm{GFP}^{+} \mathrm{MG}$ in the injected lateral ventricle (Figure 8A) and in the spinal cord at segment T8-T9 adjacent to the ependyma of the central canal associated with $\mathrm{CD}^{+}$cells (Figure $8 \mathrm{~B}$ ). There were no detectable differences in the migration of $\mathrm{MG}_{(-)}$and $\mathrm{MG}_{(\mathrm{IL}-4)}$.

\section{Discussion}

The results of this study lead us to attribute a novel role to MG as both supporters and blockers of oligodendrocyte renewal from the endogenous NPC pool in the adult CNS. The in vitro findings showed that $\mathrm{MG}_{(\mathrm{IL}-4)}$, in part via production of IGF-I and downregulation of TNF- $\alpha$, were remarkably potent in counteracting the impediment to oligodendrogenesis induced by high-dose IFN- $\gamma$. In vivo, $\mathrm{MG}_{(\mathrm{IL}-4)}$ supported oligodendrogenesis and clinical recovery in rats and mice in which severe inflammatory conditions are known to evoke clinical symptoms of transient or chronic EAE.
Defense mechanisms in the form of activated MG commonly operate in acute and chronic neurodegenerative conditions, but often the CNS is unable to tolerate them $(10,37)$. As a result, activated MG have generally been viewed as a uniformly hostile cell population that causes inflammation, interferes with cell survival (38), and blocks neurogenesis $(3,4)$. Recent studies have shown, however, that whether the effect of activated MG on the injured or inflamed CNS will be positive or negative is determined by the type of activation, and that just as activated MG can be inimical to cell survival in some instances, they can be protective in others $(14,19,20,39)$.

In the present study we showed that injection of $\mathrm{MG}_{(\mathrm{IL}-4)}$ into the CSF of rats and mice suffering from acute or chronic EAE caused an increase in the number of newly formed MG. Most of the new MG expressed MHC class II and IGF-I. Recent evidence supports the active participation of IGF-I in maintenance of the integrity and homeostasis of the CNS. This growth factor was shown, for example, to play an important role in the differentiation $(22,40)$ and survival $(41,42)$ of oligodendrocytes and to be beneficial in the treatment of $\operatorname{EAE}(43,44)$. It seems reasonable to assume that the IGF-I produced by $\mathrm{MG}_{(\mathrm{IL}-4)}$ is responsible, at least in part, for the shift to a Th2 phenotype (45) and thus for the increased number of $\mathrm{MHC}$ class $\mathrm{II}^{+} \mathrm{MG}$ as well as of the newly formed $\mathrm{BrdU}^{+} / \mathrm{MHC}$ class $\mathrm{II}^{+} \mathrm{MG}$ expressing IGF-I. The increased oligodendrogenesis was found to correlate with a higher incidence of newly formed $\mathrm{MHC}$ class $\mathrm{II}^{+} \mathrm{MG}$. In view of these findings, it might be worth considering noninvasive therapeutic intervention with IGF-I (46) or with some of the growth factors (47) that have a similar effect to that of IL-4 but are able to pass through the blood-brain barrier, rather than - or in addition to - activated MG. Delivering drugs directly to the CNS along the olfactory and trigeminal nerves could also potentially be used to target IL-4 to the CNS. The intranasal method has already been utilized for delivery of other cytokines to the CNS (48).

The finding that newly formed MG express MHC class II in vivo suggests that these MG exert their effects on oligodendrogenesis by acting as antigen-presenting cells for $\mathrm{CD}^{+}$helper $\mathrm{T}$ cells (13, 49). Alternatively, it is possible that the signal transduction pathway activated by IL-4 for IGF-I production is the same pathway as the one needed for MHC class II expression. This would mean that MHC class II expression by MG is not a requirement for oligodendrogenesis but is nevertheless correlated with it. In either case, our results contradict the traditional belief that parenchymal MHC class II-bearing MG are associated only with pathology $(29,30)$. Support for our contention comes from a recent suggestion that parenchymal MG expressing MHC class II are not required for induction of EAE (50). Our preliminary data from experiments in transgenic mice with conditional expression of diphtheria toxin receptor on $\mathrm{CD} 11 \mathrm{c}^{+}$promoter (51) suggest that MG are responsible for the induced oligodendrogenesis observed after vaccination (data not shown).

Given the rapid rate of improvement in rats with clinical symptoms of acute EAE, it seems unlikely that the observed recovery in this model is an outcome of the induced oligodendrogenesis. It is more likely that the phenomena of improved recovery and enhanced oligodendrogenesis are unrelated and that both can be attributed in part to growth factors (such as IGF-I) produced locally by $\mathrm{MG}_{(\mathrm{IL}-4)}$. IGF-I has been shown to be beneficial for neural tissue survival and renewal $(19,22,23,52-56)$. It should be borne in mind, however, that any growth factor or cytokine may exhibit 
a broad spectrum of activity even for the same indication, depending on the context and dosage. As an example, treatment with IGF-I fails to enhance CNS myelin repair during autoimmune demyelination (57). Moreover, the effect of $\mathrm{MG}_{(\mathrm{IL}-4)}$ on oligodendrogenesis under in vitro conditions was completely blocked by anti-IGF-I (23). A similar finding was reported for TNF- $\alpha$, and the detrimental effect of this cytokine might also be dependent on context and dosing $(58,59)$.

Previous studies of rats and mice with EAE showed that the inflammatory response not only induces proliferation and mobilization of endogenous progenitors (60) but also attracts exogenously delivered adult NPCs (33), implying that autoimmune brain inflammation, even in the presence of a large proportion of Th1 cells and hence of abundant IFN- $\gamma$, leads to conditions that promote cell renewal. This suggestion is further supported by the present finding that even in the absence of treatment, rats with monophasic EAE exhibited a dramatic increase in the number of newly formed oligodendrocytes compared with naive rats. This oligodendrogenesis was further increased after injection of $\mathrm{MG}_{(\mathrm{IL}-4)}$. It thus appears that encephalitogenic T cells, meaning T cells that recognize self antigens in the CNS even if the quantity and affinity of the $T$ cells are such that they cause transient paralysis, can promote oligodendrogenesis from the endogenous NPCs found along the ependymal layer lining the central canal of the spinal cord (2). Our contention that oligodendrogenesis requires $\mathrm{MG} /$ macrophages activated in a certain way is supported by a recent report that minocycline, in addition to downregulating MHC class II expression by MG/macrophages (32), also impairs remyelination.

Interestingly, in the rat model of acute EAE, significantly more new oligodendrocytes were observed in the gray matter than in the white matter. In the mouse model of chronic EAE, however, the white matter contained significantly more new oligodendrocytes than did the gray matter. The difference might be the result of the different times, in relation to the BrdU injection, at which the animals were killed. In the rat model BrdU injections were started on day 14 after immunization, and the rats were killed 7 days later. In the mouse model BrdU was injected on day 20 after immunization, and the mice were killed 12 days later. Thus it is possible that in the rat model, proliferating progenitors (probably originating in the central canal; refs. 2, 61) began differentiating into oligodendrocytes while still in the gray matter, i.e., before migrating to the white matter. This might explain why in the mouse model examination of newly formed oligodendrocytes at later stages showed most of them in the white matter, having migrated there from the gray matter. We do not rule out the possibility, albeit less likely, that mice and rats have different progenitor cell populations originating at different locations of the spinal cord (2). Examination of the primary location of these progenitors is beyond the scope of this work.

The results of this study suggest what we believe to be a novel role for $\mathrm{MG}$ in ameliorating EAE and promoting differentiation of oligodendrocytes from adult NPCs (22). They also point to a link within the known beneficial effect of IL-4 in ameliorating EAE (6, 25-27), the role of IGF-I derived from $\mathrm{MG}_{(\mathrm{IL}-4)}$, and the requirement of viable MG for remyelination (62). Our findings thus support a key role for MG in promoting cell renewal from endogenous progenitors under pathological conditions (63). This notion is in line with the proposal that autoantibodies are needed for remyelination (64). On the basis of the present findings, as well as our previously reported results, we suggest that the cross-talk between T cells and MG lays the foundation for protection and repair in the adult CNS. We further claim that although administration of immunosuppressive treatment alone (with the aim of paralyzing inflammation-associated MG; refs. 7, 8; or T cells; ref. 65) is likely to ameliorate clinical signs at an early stage, it could yield adverse effects in the longer term. This argument is supported by both experimental and clinical data (66). We therefore suggest that rather than suppression, immunomodulation aimed at appropriate and well-controlled activation of MG might be the approach to adopt in designing ways to promote cell renewal under neurodegenerative conditions.

\section{Methods}

Animals. Inbred adult male Lewis rats (12 weeks old), neonatal Lewis rats (P0-P1), adult male C57BL/6J mice (8-10 weeks old), neonatal C57BL/6J mice (P0-P1), and C57BL/6-CX 3 CR1-GFP heterozygous $\left(\mathrm{CX}_{3} \mathrm{CR} 1 /{ }^{G F P /+}\right)$ knock-in mice (34) were used. All animals were supplied by the Animal Breeding Center of The Weizmann Institute of Science, and all experiments and procedures were approved by the Weizmann Institute's Animal Care and Use Committee.

Reagents. Recombinant rat and mouse IFN- $\gamma$ and IL-4 (both containing endotoxin at a concentration below $0.1 \mathrm{ng} / \mu \mathrm{g}$ cytokine) and goat antimouse neutralizing anti-TNF- $\alpha$ antibodies (containing endotoxin at a concentration below $0.001 \mathrm{EU} / \mu \mathrm{g} \mathrm{Ab}$ ) were obtained from R\&D Systems.

NPC culture. Coronal sections ( $2 \mathrm{~mm}$ thick) of tissue containing the subventricular zone of the lateral ventricle were obtained from the brains of adult $\mathrm{C} 57 \mathrm{BL} / 6 \mathrm{~J}$ mice. The tissue was minced and then incubated for digestion at $37^{\circ} \mathrm{C}, 5 \% \mathrm{CO}_{2}$ for 45 minutes in Earle's balanced salt solution containing $0.94 \mathrm{mg} / \mathrm{ml}$ papain (Worthington Biochemical Corp.) and $0.18 \mathrm{mg} / \mathrm{ml} \mathrm{L-cyste-}$ ine and EDTA. After centrifugation at $110 \mathrm{~g}$ for 15 minutes at room temperature, the tissue was mechanically dissociated by pipette trituration. Cells obtained from single-cell suspensions were plated $\left(3,500\right.$ cells $\left./ \mathrm{cm}^{2}\right)$ in $75-\mathrm{cm}^{2}$ Falcon tissue-culture flasks (BD Biosciences) in NPC-culturing medium (DMEM/F12 medium; Invitrogen Corp.; containing $2 \mathrm{mM}$ L-glutamine, $0.6 \%$ glucose, $9.6 \mu \mathrm{g} / \mathrm{ml}$ putrescine, $6.3 \mathrm{ng} / \mathrm{ml}$ progesterone, $5.2 \mathrm{ng} / \mathrm{ml}$ sodium selenite, $0.02 \mathrm{mg} / \mathrm{ml}$ insulin, $0.1 \mathrm{mg} / \mathrm{ml}$ transferrin, and $2 \mu \mathrm{g} / \mathrm{ml}$ heparin; all from Sigma-Aldrich; and fibroblast growth factor-2 [human recombinant, $20 \mathrm{ng} / \mathrm{ml}$ ] and epidermal growth factor [human recombinant, $20 \mathrm{ng} / \mathrm{ml}$ ]; both from PeproTech). Spheres were passaged every 4-6 days and replated as single cells. GFP-expressing NPCs were obtained as previously described (33).

Primary microglial culture. Brains from neonatal (P0-P1) C57BL/6J mice or Lewis rats were stripped of their meninges and minced with scissors under a dissecting microscope (Stemi DV4; Zeiss) in Leibovitz-15 medium (Biological Industries). After trypsinization (0.5\% trypsin for 10 minutes at $37^{\circ} \mathrm{C}, 5 \% \mathrm{CO}_{2}$ ), the tissue was triturated. The cell suspension was washed in culture medium for glial cells (DMEM supplemented with $10 \%$ FCS [Sigma-Aldrich], $1 \mathrm{mM}$ L-glutamine, $1 \mathrm{mM}$ sodium pyruvate, $100 \mathrm{U} / \mathrm{ml}$ penicillin, and $100 \mathrm{mg} / \mathrm{ml}$ streptomycin) and cultured at $37^{\circ} \mathrm{C}, 5 \% \mathrm{CO}_{2}$ in $75-\mathrm{cm}^{2}$ Falcon tissue-culture flasks (BD Biosciences) coated with poly-Dlysine (PDL; $10 \mathrm{mg} / \mathrm{ml}$; Sigma-Aldrich) in borate buffer (2.37 g borax and $1.55 \mathrm{~g}$ boric acid dissolved in $500 \mathrm{ml}$ sterile water, $\mathrm{pH}$ 8.4) for 1 hour, then rinsed thoroughly with sterile, glass-distilled water. Half of the medium was changed after 6 hours in culture and every second day thereafter, starting on day 2, for a total culture time of 10-14 days. MG were shaken off the primary mixed brain glial cell cultures $\left(150 \mathrm{rpm}, 37^{\circ} \mathrm{C}, 6\right.$ hours $)$ with maximum yields between days 10 and 14 , seeded $\left(10^{5}\right.$ cells $\left./ \mathrm{ml}\right)$ onto PDLpretreated 24-well plates ( $1 \mathrm{ml} /$ well; Corning Incorporated), and grown in culture medium for MG (RPMI-1640 medium; Sigma-Aldrich; supplemented with $10 \%$ FCS, $1 \mathrm{mM}$ L-glutamine, $1 \mathrm{mM}$ sodium pyruvate, $50 \mathrm{mM}$ $\beta$-mercaptoethanol, $100 \mathrm{U} / \mathrm{ml}$ penicillin, and $100 \mathrm{mg} / \mathrm{ml}$ streptomycin). The cells were allowed to adhere to the surface of a PDL-coated culture flask for 1 hour at $37^{\circ} \mathrm{C}, 5 \% \mathrm{CO}_{2}$, and nonadherent cells were rinsed off. 
Coculturing of mouse NPCs and mouse MG. Mouse MG were treated for 24 hours with cytokines (IFN- $\gamma, 10 \mathrm{ng} / \mathrm{ml}$ or $100 \mathrm{ng} / \mathrm{ml}$, and IL-4, $10 \mathrm{ng} / \mathrm{ml}$ ). Cultures of treated or untreated MG were washed twice with fresh NPC differentiation medium (same as the culture medium for NPCs but without growth factors and with $2.5 \%$ FCS) to remove all traces of the tested reagents, then incubated on ice for 15 minutes and shaken at $350 \mathrm{rpm}$ for 20 minutes at room temperature. MG were removed from the flasks and immediately cocultured with NPCs $\left(5 \times 10^{4}\right.$ cells/well for both types of cells) for 10 days on cover slips coated with Matrigel (BD Biosciences) in 24-well plates in the presence of NPC differentiation medium. The cultures were then fixed with $2.5 \%$ paraformaldehyde in PBS for 30 minutes at room temperature and stained for neuronal and glial markers.

Induction and evaluation of acute and chronic EAE. To induce chronic EAE we injected adult male C57BL/6J mice s.c. with $200 \mu \mathrm{g}(300 \mu \mathrm{l})$ of $_{\text {MOG }} 35-55$ (Sigma-Aldrich) in incomplete Freund's adjuvant containing $2.5 \mathrm{mg} / \mathrm{ml} \mathrm{M}$. tuberculosis (strain H37Ra; BD Diagnostics). Pertussis toxin (500 ng; SigmaAldrich) was injected on the day of the immunization and again 2 days later.

To induce monophasic EAE, we immunized adult male Lewis rats s.c. in the hind footpad with $25 \mu \mathrm{g}$ MBP 68-86, emulsified (1:1 dilution) in $100 \mu \mathrm{l}$ of complete Freund's adjuvant containing $2 \mathrm{mg}$ M. tuberculosis (strain H37Ra, BD Diagnostics). Clinical signs were evaluated in a blinded fashion by at least 2 investigators. Body weight and clinical score were recorded daily ( 0 , healthy; 1 , limb tail paralysis; 2 , ataxia and/or paresis of hind limbs; 3 , paralysis of hind limbs and/or paresis of forelimbs; 4, tetraparalysis; 5 , moribund state or death).

Stereotaxic injection of activated $M G$. Seven days after the vaccination, Lewis rats with monophasic EAE were injected bilaterally with syngeneic $\mathrm{MG}_{(-)}$, $10 \mathrm{ng} / \mathrm{ml} \mathrm{MG}_{(\mathrm{IFN}-\gamma)}, 10 \mathrm{ng} / \mathrm{ml} \mathrm{MG}_{(\mathrm{IL}-4)}$, or PBS stereotaxically $\left(1 \times 10^{5}\right.$ cells in $5 \mu \mathrm{l}$ PBS for 5 minutes) into the CSF via the brain lateral ventricles (Bregma, $-0.8 ; \mathrm{L}, 1.2 ; \mathrm{V}, 4.5$ ). Ten days after the vaccination, C57BL/6J mice with chronic EAE received bilateral stereotaxic injections of syngeneic $\mathrm{MG}_{(\mathrm{IL}-4)}$ or PBS $\left(1 \times 10^{5}\right.$ cells in $3 \mu \mathrm{l}$ PBS for 3 minutes $)$ into the CSF via the brain lateral ventricles (Bregma, -0.4; L, 0.8; V, 2.5).

Administration of BrdU and tissue preparation. The cell-proliferation marker BrdU was dissolved by sonication in PBS and injected i.p. (50 mg/kg body weight) every 12 hours for 2.5 days starting on day 14 after MBP vaccination in adult male Lewis rats or on day 20 after MOG vaccination in adult male C57BL/6J mice. One week (for rats) or 2 weeks (for mice) after the first BrdU injection, the animals were deeply anesthetized and perfused transcardially, first with PBS and then with $4 \%$ paraformaldehyde. Their spinal cords were removed, postfixed overnight, and then equilibrated in phosphate-buffered $30 \%$ sucrose. Free-floating $30-\mu \mathrm{m}$ longitudinal sections were collected on a freezing microtome (SM2000R; Leica Microsystems) and stored at $4{ }^{\circ} \mathrm{C}$ prior to immunohistochemistry.

Immunocytochemistry and immunobistochemistry. Cover slips from cocultures of NPCs and mouse MG were washed with PBS; fixed as described above; treated with a permeabilization/blocking solution containing $10 \%$ FCS, $2 \%$ bovine serum albumin, $1 \%$ glycine, and $0.1 \%$ Triton X-100 (SigmaAldrich); and stained with a combination of the rabbit anti-NG2 chondroitin sulfate proteoglycan (1:500 dilution) and mouse anti-RIP (1:2,000 dilution). To capture the MG we used FITC-conjugated Bandeiraea simplicifolia IB4 (1:50 dilution; Sigma-Aldrich). Expression of IGF-I was detected by goat anti-IGF-I (1:20 dilution; R\&D Systems).

For immunohistochemistry, longitudinal sections of the spinal cord or coronal sections of the brain $(30 \mu \mathrm{m})$ were treated with a permeabilization/blocking solution containing 10\% FCS, $2 \%$ bovine serum albumin, $1 \%$ glycine, and $0.05 \%$ Triton X-100 (Sigma-Aldrich). Primary antibodies were applied for 1 hour in a humidified chamber at room temperature. For BrdU staining, sections were washed with PBS and incubated in $2 \mathrm{~N} \mathrm{HCl}$ at $37^{\circ} \mathrm{C}$ for 30 minutes. Sections were blocked for 1 hour with blocking solution. The tissue was then stained with rat anti-BrdU (1:200 dilution; Oxford Biotechnology Ltd.) in combination with rabbit anti-NG2 (1:300 dilution) and mouse anti-RIP (1:1,000 dilution) antibodies diluted in PBS containing $0.05 \%$ Triton X-100, $0.1 \%$ Tween 20, and 2\% horse serum. For labeling of MG we used IB4 (1:50 dilution). To detect expression of cell-surface MHC class II proteins we used mouse anti-MHC class II Abs (1:50 dilution; IQ Products). Expression of IGF-I was detected by goat anti-IGF-I Abs (1:10-1:100 dilution; R\&D Systems). T cells were detected with anti-CD3 Abs (1:200 dilution; SouthernBiotech). Sections were incubated with the primary antibody for 24 hours at $4^{\circ} \mathrm{C}$, washed with PBS, and incubated with the secondary antibodies in PBS for 1 hour at room temperature while protected from light. Secondary antibodies used for both immunocytochemistry and immunohistochemistry were $\mathrm{Cy}-3$-conjugated donkey anti-mouse, Cy-3-conjugated goat anti-rabbit, $\mathrm{Cy}-5$-conjugated goat anti-rat, $\mathrm{Cy}-2-$ conjugated goat anti-rat, and Cy-5-conjugated donkey anti-goat. All antibodies were purchased from Jackson ImmunoResearch Laboratories Inc. and used at a dilution of 1:250-1:500. Control sections (not treated with primary antibody) were used to distinguish specific staining from staining of nonspecific antibodies or autofluorescent components. Sections were then washed with PBS and coverslipped in polyvinyl alcohol with diazabicylo-octane as anti-fading agent.

Q-PCR analysis. Total cellular RNA purification and cDNA synthesis was performed as described previously (19). We assayed the expression of specific mRNAs using Q-PCR with selected gene-specific primer pairs. Q-PCR reactions were performed with a high-speed thermal cycler (LightCycler; Roche Diagnostics Corp.), and the product was detected by FastStart Master SYBR Green I (Roche Molecular Biochemicals) according to the manufacturer's instructions. The amplification cycle was $95^{\circ} \mathrm{C}$ for 10 seconds, $60^{\circ} \mathrm{C}$ for 5 seconds, and $72^{\circ} \mathrm{C}$ for 10 seconds. The primers used for IGF-I were sense, $5^{\prime}$-CCGGACCAGAGACCCTTTG-3'; antisense, $5^{\prime}$-CCTGTGGGCTTGTTGAAGTAAAA-3'; and for TNF- $\alpha$ were sense 5'-ACAAGGCTGCCCCGACTAT-3'; antisense, 5'-CTCCTGGTATGAAGTGGCAAATC-3'. Melting curve analysis confirmed that only 1 product was amplified.

Quantification and stereological counting procedure. For microscopic analysis we used a Zeiss LSM 510 confocal laser scanning microscope (magnification, $\times 40)$. For experiments in vitro we scanned fields of $0.053 \mathrm{~mm}^{2}(n=8-16$ from at least 2 different coverslips) for each experimental group. For each marker, 500-1,000 cells were sampled. Cells coexpressing GFP, NG2, and RIP were counted.

For in vivo experiments with rats and mice with EAE, oligodendrogenesis and proliferation of MG in the spinal cord were evaluated by counting cells that were double or triple labeled with BrdU and markers of premature oligodendrocytes (NG2), MG (IB4), antigen-presenting cells (MHC class II), or a pre-ensheathing marker of oligodendrocytes (RIP) from sagittal longitudinal sections at segment T8-T9 of the spinal cord. The number of cells per cubic millimeter were counted at $300-\mu \mathrm{m}$ intervals in gray and white matter in each rat ( $n=5-8$ per group) or mouse ( $n=4$ per group). Specificity of $\mathrm{BrdU}^{+} / \mathrm{NG}^{+}, \mathrm{BrdU}^{+} / \mathrm{RIP}^{+}, \mathrm{BrdU}^{+} / \mathrm{IB}^{+}$, or $\mathrm{BrdU}^{+} / \mathrm{IB}^{+} / \mathrm{MHC}$ class $\mathrm{II}^{+}$coexpression was assayed using the confocal microscope (LSM 510; Zeiss) in optical sections at $1-\mu \mathrm{m}$ intervals. Counting was evaluated automatically using Image-Pro Plus 4.5 software (MediaCybernetics).

Statistics. The in vitro results were analyzed by Tukey-Kramer multiple comparison ANOVA and are expressed as mean $\pm \mathrm{SD}$. In vivo results were analyzed by 2-tailed Student's $t$ test or 1-way ANOVA and are expressed as mean \pm SEM. Significance of the EAE score was analyzed by Mann-Whitney test, 2-factor repeated measures ANOVA. 


\section{Acknowledgments}

We thank S.R. Smith for editing the manuscript. M. Schwartz holds the Maurice and Ilse Katz Professorial Chair in Neuroimmunology. S. Jung is the incumbent of the Pauline Recanati Career Development Chair and a Scholar of the Benoziyo Center for Molecular Medicine. The work was supported by Proneuron Ltd. and by The Erwin Green Alzheimer's Research Fund.
Received for publication September 12, 2005, and accepted in revised form February 7, 2006.

Address correspondence to: Michal Schwartz, Department of Neurobiology, Weizmann Institute of Science, PO Box 26, 76100 Rehovot, Israel. Phone: 972-8-93-42467; Fax: 972-8-93-46018; E-mail: michal.schwartz@weizmann.ac.il.
1. Eriksson, P.S., et al. 1998. Neurogenesis in the adult human hippocampus. Nat. Med. 4:1313-1317.

2. Horner, P.J., et al. 2000. Proliferation and differentiation of progenitor cells throughout the intact adult rat spinal cord. J. Neurosci. 20:2218-2228.

3. Monje, M.L., Toda, H., and Palmer, T.D. 2003. Inflammatory blockade restores adult hippocampal neurogenesis. Science. 302:1760-1765.

4. Ekdahl, C.T., Claasen, J.H., Bonde, S., Kokaia, Z., and Lindvall, O. 2003. Inflammation is detrimental for neurogenesis in adult brain. Proc. Natl. Acad. Sci. U. S. A. 100:13632-13637.

5. Hartung, H.P., et al. 1992. Inflammatory mediators in demyelinating disorders of the CNS and PNS. J. Neuroimmunol. 40:197-210.

6. Olsson, T. 1995. Critical influences of the cytokine orchestration on the outcome of myelin antigenspecific T-cell autoimmunity in experimental autoimmune encephalomyelitis and multiple sclerosis. Immunol. Rev. 144:245-268.

7. Heppner, F.L., et al. 2005. Experimental autoimmune encephalomyelitis repressed by microglial paralysis. Nat. Med. 11:146-152.

8. Huitinga, I., van Rooijen, N., de Groot, C.J., Uitdehaag, B.M., and Dijkstra, C.D. 1990. Suppression of experimental allergic encephalomyelitis in Lewis rats after elimination of macrophages. J. Exp. Med. 172:1025-1033.

9. Probert, L., et al. 1997. TNF-alpha transgenic and knockout models of CNS inflammation and degeneration. J. Neuroimmunol. 72:137-141.

10. Merrill, J.E., Ignarro, L.J., Sherman, M.P., Melinek, J., and Lane, T.E. 1993. Microglial cell cytotoxicity of oligodendrocytes is mediated through nitric oxide. J. Immunol. 151:2132-2141.

11. Chao, C.C., Hu, S., Molitor, T.W., Shaskan, E.G., and Peterson, P.K. 1992. Activated microglia mediate neuronal cell injury via a nitric oxide mechanism. J. Immunol. 149:2736-2741.

12. Stirling, D.P., et al. 2004. Minocycline treatment reduces delayed oligodendrocyte death, attenuates axonal dieback, and improves functional outcome after spinal cord injury. J. Neurosci. 24:2182-2190.

13. Bieber, A.J., Kerr, S., and Rodriguez, M. 2003. Efficient central nervous system remyelination requires T cells. Ann. Neurol. 53:680-684.

14. Schwartz, M., Shaked, I., Fisher, J., Mizrahi, T., and Schori, H. 2003. Protective autoimmunity against the enemy within: fighting glutamate toxicity. Trends Neurosci. 26:297-302.

15. Hauben, E., and Schwartz, M. 2003. Therapeutic vaccination for spinal cord injury: helping the body to cure itself. Trends Pharmacol. Sci. 24:7-12.

16. Moalem, G., et al. 1999. Autoimmune T cells protect neurons from secondary degeneration after central nervous system axotomy. Nat. Med. 5:49-55.

17. Butovsky, O., Hauben, E., and Schwartz, M. 2001. Morphological aspects of spinal cord autoimmune neuroprotection: colocalization of T cells with B7-2 (CD86) and prevention of cyst formation. FASEB J. 15:1065-1067.

18. Shaked, I., Porat, Z., Gersner, R., Kipnis, J., and Schwartz, M. 2004. Early activation of microglia as antigen-presenting cells correlates with $\mathrm{T}$ cellmediated protection and repair of the injured central nervous system. J. Neuroimmunol. 146:84-93.

19. Butovsky, O., Talpalar, A.E., Ben-Yaakov, K., and Schwartz, M. 2005. Activation of microglia by aggregated beta-amyloid or lipopolysaccharide impairs MHC-II expression and renders them cytotoxic whereas IFN-gamma and IL-4 render them protective. Mol. Cell. Neurosci. 29:381-393.

20. Shaked, I., et al. 2005. Protective autoimmunity: interferon-gamma enables microglia to remove glutamate without evoking inflammatory mediators. J. Neurochem. 92:997-1009.

21. Wildbaum, G., Nahir, M.A., and Karin, N. 2003. Beneficial autoimmunity to proinflammatory mediators restrains the consequences of selfdestructive immunity. Immunity. 19:679-688.

22. Hsieh, J., et al. 2004. IGF-I instructs multipotent adult neural progenitor cells to become oligodendrocytes. J. Cell Biol. 164:111-122.

23. Butovsky, O., et al. 2005. Microglia activated by IL-4 or IFN-gamma differentially induce neurogenesis and oligodendrogenesis from adult stem/progenitor cells. Mol. Cell. Neurosci. 31:149-160.

24. Mothe, A.J., and Tator, C.H. 2005. Proliferation, migration, and differentiation of endogenous ependymal region stem/progenitor cells following minimal spinal cord injury in the adult rat. Neuroscience. 131:177-187.

25. Aharoni, R., Teitelbaum, D., Sela, M., and Arnon, R. 1997. Copolymer 1 induces T cells of the Thelper type 2 that crossreact with myelin basic protein and suppress experimental autoimmune encephalomyelitis. Proc. Natl. Acad. Sci. U. S. A. 94:10821-10826.

26. Xu, L.Y., et al. 2000. Suppression of ongoing experimental allergic encephalomyelitis (EAE) in Lewis rats: synergistic effects of myelin basic protein (MBP) peptide 68-86 and IL-4. Clin. Exp. Immunol. 120:526-531.

27. Furlan, R., et al. 2001. Central nervous system gene therapy with interleukin-4 inhibits progression of ongoing relapsing-remitting autoimmune encephalomyelitis in Biozzi AB/H mice. Gene Ther. 8:13-19.

28. Duda, P.W., Schmied, M.C., Cook, S.L., Krieger, J.I., and Hafler, D.A. 2000. Glatiramer acetate (Copaxone) induces degenerate, Th2-polarized immune responses in patients with multiple sclerosis. J. Clin. Invest. 105:967-976.

29. Juedes, A.E., and Ruddle, N.H. 2001. Resident and infiltrating central nervous system APCs regulate the emergence and resolution of experimental autoimmune encephalomyelitis. J. Immunol. 166:5168-5175.

30. Olsson, T. 1992. Cytokines in neuroinflammatory disease: role of myelin autoreactive $\mathrm{T}$ cell production of interferon-gamma. J. Neuroimmunol. 40:211-218.

31. Neumann, H., Misgeld, T., Matsumuro, K., and Wekerle, H. 1998. Neurotrophins inhibit major histocompatibility class II inducibility of microglia: involvement of the p75 neurotrophin receptor. Proc. Natl. Acad. Sci. U. S. A. 95:5779-5784.

32. Li, W.W., Setzu, A., Zhao, C., and Franklin, R.J. 2005. Minocycline-mediated inhibition of microglia activation impairs oligodendrocyte progenitor cell responses and remyelination in a nonimmune model of demyelination. J. Neuroimmunol. 158:58-66.

33. Pluchino, S., et al. 2003. Injection of adult neurospheres induces recovery in a chronic model of multiple sclerosis. Nature. 422:688-694.

34. Jung, S., et al. 2000. Analysis of fractalkine receptor CX(3)CR1 function by targeted deletion and green fluorescent protein reporter gene insertion. Mol. Cell. Biol. 20:4106-4114.

35. Davalos, D., et al. 2005. ATP mediates rapid microglial response to local brain injury in vivo. Nat. Neurosci. 8:752-758.

36. Geissmann, F., Jung, S., and Littman, D.R. 2003. Blood monocytes consist of two principal subsets with distinct migratory properties. Immunity. 19:71-82.

37. Dijkstra, C.D., De Groot, C.J., and Huitinga, I. 1992. The role of macrophages in demyelination. J. Neuroimmunol. 40:183-188.

38. Popovich, P.G., et al. 2002. The neuropathologi$\mathrm{cal}$ and behavioral consequences of intraspinal microglial/macrophage activation. J. Neuropathol. Exp. Neurol. 61:623-633.

39. Mitrasinovic, O.M., et al. 2005. Microglia overexpressing the macrophage colony-stimulating factor receptor are neuroprotective in a microglialhippocampal organotypic coculture system. J. Neurosci. 25:4442-4451.

40. Mason, J.L., and Goldman, J.E. 2002. A2B5+ and $\mathrm{O} 4+$ cycling progenitors in the adult forebrain white matter respond differentially to PDGF-AA, FGF-2, and IGF-1. Mol. Cell. Neurosci. 20:30-42.

41. Barres, B.A., Schmid, R., Sendnter, M., and Raff, M.C. 1993. Multiple extracellular signals are required for long-term oligodendrocyte survival. Development. 118:283-295.

42. Mason, J.L., Ye, P., Suzuki, K., D’Ercole, A.J., and Matsushima, G.K. 2000. Insulin-like growth factor-1 inhibits mature oligodendrocyte apoptosis during primary demyelination. J. Neurosci. 20:5703-5708.

43. Liu, X., et al. 1994. Astrocytes express insulin-like growth factor-I (IGF-I) and its binding protein, IGFBP-2, during demyelination induced by experimental autoimmune encephalomyelitis. Mol. Cell. Neurosci. 5:418-430.

44. Hinks, G.L., and Franklin, R.J. 2000. Delayed changes in growth factor gene expression during slow remyelination in the CNS of aged rats. Mol. Cell. Neurosci. 16:542-556.

45. Kooijman, R., and Coppens, A. 2004. Insulin-like growth factor-I stimulates IL-10 production in human T cells. J. Leukoc. Biol. 76:862-867.

46. Thorne, R.G., Pronk, G.J., Padmanabhan, V., and Frey, W.H., 2nd. 2004. Delivery of insulin-like growth factor-I to the rat brain and spinal cord along olfactory and trigeminal pathways following intranasal administration. Neuroscience. 127:481-496.

47. Jin, K., et al. 2003. Cerebral neurogenesis is induced by intranasal administration of growth factors. Ann. Neurol. 53:405-409.

48. Ross, T.M., et al. 2004. Intranasal administration of interferon beta bypasses the blood-brain barrier to target the central nervous system and cervical lymph nodes: a non-invasive treatment strategy for multiple sclerosis. J. Neuroimmunol. 151:66-77.

49. Arnett, H.A., Wang, Y., Matsushima, G.K., Suzuki, K., and Ting, J.P. 2003. Functional genomic analysis of remyelination reveals importance of inflammation in oligodendrocyte regeneration. J. Neurosci. 23:9824-9832.

50. Greter, M., et al. 2005. Dendritic cells permit immune invasion of the CNS in an animal model of multiple sclerosis. Nat. Med. 11:328-334.

51. Jung, S., et al. 2002. In vivo depletion of CD11c(+) dendritic cells abrogates priming of CD8 $(+) \mathrm{T}$ cells 
by exogenous cell-associated antigens. Immunity. 17:211-220.

52. Mason, J.L., Xuan, S., Dragatsis, I., Efstratiadis, A., and Goldman, J.E. 2003. Insulin-like growth factor (IGF) signaling through type 1 IGF receptor plays an important role in remyelination. J. Neurosci. 23:7710-7718.

53. Ness, J.K., and Wood, T.L. 2002. Insulin-like growth factor I, but not neurotrophin-3, sustains Akt activation and provides long-term protection of immature oligodendrocytes from glutamate-mediated apoptosis. Mol. Cell. Neurosci. 20:476-488.

54. Aberg, M.A., Aberg, N.D., Hedbacker, H., Oscarsson, J., and Eriksson, P.S. 2000. Peripheral infusion of IGF-I selectively induces neurogenesis in the adult rat hippocampus. J. Neurosci. 20:2896-2903.

55. Trejo, J.L., Carro, E., and Torres-Aleman, I. 2001. Circulating insulin-like growth factor I mediates exercise-induced increases in the number of new neurons in the adult hippocampus. J. Neurosci. 21:1628-1634.
56. Dudek, H., et al. 1997. Regulation of neuronal survival by the serine-threonine protein kinase Akt. Science. 275:661-665.

57. Cannella, B., Pitt, D., Capello, E., and Raine, C.S 2000. Insulin-like growth factor-1 fails to enhance central nervous system myelin repair during autoimmune demyelination. Am. J. Pathol. 157:933-943.

58. Bruce, A.J., et al. 1996. Altered neuronal and microglial responses to excitotoxic and ischemic brain injury in mice lacking TNF receptors. Nat. Med. 2:788-794.

59. Frei, K., et al. 1997. Tumor necrosis factor alpha and lymphotoxin alpha are not required for induction of acute experimental autoimmune encephalomyelitis. J. Exp. Med. 185:2177-2182.

60. Picard-Riera, N., et al. 2002. Experimental autoimmune encephalomyelitis mobilizes neural progenitors from the subventricular zone to undergo oligodendrogenesis in adult mice. Proc. Natl. Acad. Sci. U. S. A. 99:13211-13216.

61. Morshead, C.M., et al. 1994. Neural stem cells in the adult mammalian forebrain: a relatively quiescent subpopulation of subependymal cells. Neuron. 13:1071-1082.

62. Kotter, M.R., Setzu, A., Sim, F.J., Van Rooijen, N., and Franklin, R.J. 2001. Macrophage depletion impairs oligodendrocyte remyelination following lysolecithin-induced demyelination. Glia. 35:204-212.

63. Ziv, Y., et al. 2006. T cells - immune cells contribute to the maintenance of neurogenesis and spatial learning abilities in adulthood. Nat. Neurosci. 9:268-275.

64. van Engelen, B.G., Pavelko, K.D., and Rodriguez, M. 1997. Enhancement of central nervous system remyelination in immune and non-immune experimental models of demyelination. Mult. Scler. 3:76-79.

65. Yednock, T.A., et al. 1992. Prevention of experimental autoimmune encephalomyelitis by antibodies against alpha 4 beta 1 integrin. Nature. 356:63-66.

66. Steinman, L. 2005. Blocking adhesion molecules as therapy for multiple sclerosis: natalizumab. Nat. Rev. Drug Discov. 4:510-518. 